\title{
WOMEN IN OBBASÁ'S POETRY
}

\author{
Ayoola Oladunnke Aransi \& Hakeem Olawale \\ Kwara State University, Malete, Nigeria \\ ayoaransi@gmail.com
}

\begin{abstract}
Obasá's creativity cuts across virtually all aspects of Yorùbá socio-cultural settings and his works have attracted the attention of various scholars. It is evident that his poems are laden with topical issues that are of national interest. Most of his works, as described by previous scholars, are based on his love for and interest in Yorùbá language, social values, language, style, cultural practices, and the recovery endangered Yoruba oral art (Babalọlá 1971, 1973; Olábimtán 1974a, 1974b; Ògúnsínà 1980; Olátúnji 1982; Akínyẹmí 1987, 1991, 2017; and Nnodim 2006). This essay focuses on the representation of women in Obasáás poetry, a topic that has not been given adequate attention. The essay attempts a close reading of Obașá's poems within the Feminism and womanism theoretical frameworks. The research reveals that the representation of women in the poetry of Obasa did not go beyond the stereotypical and derogatory portrayal of women among the Yoruba.
\end{abstract}

\section{Introduction}

In Yorùbá traditional setting, the importance of women is of high repute and cannot be overemphasized. Yorùbá women are generally strong, highly intelligent, lively, expressive, determined, and devoted to their family. They are very versatile, loyal, as well as enterprising. This is aptly captured in the Ifá corpus of Ėjìogbè that, Bí ọdá owó șe n' dá mi ni Ààbò obinrin mi ń bò mí (when I was in financial crisis, Ààbò, my wife bailed me out). This Ifá excerpt corroborates the facts that women provide necessary support for their spouses. The need for a Yoruba man to be married is also encoded in the proverb, àilóbìnrin kò seé dákẹ sí, bá a dákẹ, ẹjọ ní í kó báni (an unmarried man will have to explain to people around him why he is not married). This shows that women are very important in Yoruba men's live and the society at large. However, the representation of women in Yoruba literature is nothing to write home about. According to Ogunsina (1997), 
What we have is a literature whose concern is wholly for men...To a large extent, images of women in Yorùbá traditional oral and written literary tradition are awkward and inaccurate...Women are known to have played socio-political roles... but these are usually trivialized and misrepresented by literary artists and playwrights, thus distorting our knowledge of women contributions (89).

It is gratifying to note that some contemporary Yorùbá creative writers have shown understanding in creating positive image of women. Among such writers are Àrinpé Adéjùmọ̀, Ol|úyẹemisí Adébọ̀wálé, Dúró Adélékè, Akínwùmí İṣọlá, and T.M. Ilésanmí. They all have used their creative works to redefine the representation of women. Akínyẹmí (1987: 110) notes that the most important notion of Obbasá about women is their character and beauty. Akinyemi's work critically examined Obasá's view about Yorùbá women. According to him, Obasa used his creative ingenuity and cultural understanding to present women based on his knowledge of the norms and customs of the society. He showcased sundry practices which Yorùbá women do to justify their being labeled as mothers, wives, help mates, comforters, etc. Regardless of stereotypical depiction of women among the Yorùbá people, their women are not totally marginalized.

\section{Images of Women in Obasá Poetry}

Various images of women are discernible in Obasa's poems. These are discussed in the remaining section of this essay. In Obasá's poems we found positive representation of women For instance, in one poems, he states that,

À ń sọ̀rọ obinrin

Nwọ́n ní ká sọ ọ́ bà-à-rà

Ká mẹ́nu kúrò

Bí a bá pa bàrà tán

Tani yóò lọ rè ífọ oọ? (Ọbasá, 1934: 16).

We are discussing women issues

They said we should discuss it minimally

And forget about it

After the melon creeper is harvested

Who will wash it? 
The above excerpt of Obasá's poem can be further explained through the "Odù Ogbèsẹe" in Ifá corpus which corroborates the collaboration between men and women in Yorùbá society:

İwọ $a k o$

Èmi $a b o$

E jẹ ká jọ máa tọ́jú ara wa

İwọ ò yẹ

Èmi $o ̀$ yẹ

Yangí ilé

Wọn ki i yẹlé

E jẹ ká máa tọjú ara wa (Odegbola 2014: 95).

You are male

I am female

Let us take care of each other

You stand firm

I stand firm

The basement of house

Does not fail the house

Let us take care of each other

The above excepts of Ifa and Obasa's poetry testify to the role of women in supporting the men folk in the society. Also, the excerpts show that the concerted efforts of men and women will lead to fruitfulness and productivity in the society. This is in line with Chukwuman's (1990/91) position that "(African) feminism is not a question of superiority or inferiority. It is a question of complimentarily and recognition" (7). This is in contrast to the erroneous belief that Yorùbá women are not valuable, or that they are lazy, or irrelevant. Rather, the excerpts confirm that women are diligent and that they are helpmates to men.

Ọbasá also describes women as preservers of homes, and that they are good caretakers of the domestic sphere. This is demonstrated in his poem below.

A kò lóbìnrin

À n' dá ọ̣yọ́ sí

Bía bá dá ọ̣́yọ́ sí

Ewưrẹ nífi íje

(Ọbaṣá 1982: 55).

We have no woman (wife at home)

We are preserving the corchorus olitorius vegetable 
If we preserve the corchorus olitorius vegetable

It is the goat that will eat it.

Corchorus olitorius is one of the common vegetables among the Yoruba of southwestern Nigeria. The above excerpt reveals that women, as caretakers of homes are the ones who can ensure that such vegetables, if harvested, will be properly taken care of. If women, who are the housemakers refuse to take care of the vegetable, then it will not be useful for consumption. Consequentially, the excerpt is referring to women as agent of preservation.

In Achonolonu's (1995) view, the place of women as mothers and wives in Africa is enormous. Kọ́láwọlé (1997) corroborates this assertion that, "The African women cherished her role as a homemaker as well as her status as a mother or potential mother" (30). As remarked by Sheu (2001), "woman is the one that makes life meaningful for man, without the woman, a man is incomplete" (12). African women are associated with cooking, which is regarded as part of their domestic duties. Women see cooking meals as their responsibility. This African belief about women as good cooks and as holders of domestic sphere is shown in Ọbasá's poem below:

İyàwó fàparò dálá

Ọọ șiyán jẹ (Ọbasá 1945: 21).

Wife prepares bush fowl with okro soup

The husband eats excess pounded yam

Apart from food preparations, there are other multifarious prominent roles played by women in Yorùbá society. As mothers and wives, their roles can never be overemphasized. The roles of women in African society have been discussed by many African writers who are feminist and womanist in their own right. One of such writers is Acholonu (1995) who posits that:

The African woman is known for her ability to combine several roles and to function in various capacities within her society. Because, the society depend so much on her strength and resilience as the matrix of life in its varied dimensions, it places on her the burden of embodying the two opposing qualities that confront life at all levels; she is at once the high mountain and the deep valley and beside it (24-25).

Women are presented in different ways in Obasá's poetry. The importance of women as mothers is portrayed in the excerpt below from one of his poems:

Òtọ̀ nifẹẹ baba

Olúborí nifé iyá 
Kò sóhun tí iyá

Kò lè șe nítorí ọmọ

Ọmọ mọ́ni lára bí aṣo (Ọbasá 1982: 57).

The father's love is one kind of love

(But) mother's love is the most valued

There is nothing a mother

Will not do for her child

Affinity of the child to the mother is like the garment/cloth on the body

The above depicts the role of mother to the child both in nurturing and training of child. While fathers also participate in the training of the children mothers bare the most of the burden. It is for that reason that Òpẹfèyítimí (2009) claims,

The womb to tomb continuum is, therefore indicative of man's life circle. Besides, since conception is at the beginning of life and extinction is at the expiry of the same life, it appears that at the extreme end to the left of life, women stand to originate life... she provides the first shelter for man in her stomach... This further confirms the power of women to complete man's circle of life. It is as if to say that woman is the force behind man's various movements from the womb to life (170).

Considering the assertion in the above quotation, the love of mothers for their children is greater than that of the fathers because of the incomparable intimacy between mothers and their children. The love of mothers for their children is recognized in terms of pregnancy, child delivery, breast feeding, child care, and many other obligations attached to motherhood in. This also corroborates Horney's (1967) view concerning women that, "The mother initially has complete power over the child's satisfaction of needs and forbids instinctual activities, by encouraging the child first" (11). The above view illustrates that the role of women as mothers should not be underestimated.

\section{Women and Body Politics in Obasa's Poetry}

Yorùbá regards beauty as natural gift. Also, they believe that women are naturally more beautiful than men. The belief of the Yoruba people that women are naturally elegant when compared to men is equally discernible in the poetry of Obasa. This is similar to the view expressed by Ajíbádé (2008) that, "Women are naturally elegant when compared to men: and they become 
more elegant when they use cosmetics or any other forms of make-up" (281). Obasá in his poetry appreciates the beauty of women. Here is an excerpt:

Òpẹleéngé subú làwo kò fọ́

Ó subú lodó, odó ya

Obinrin tẹéreé ye ọko rẹ nijọ ijó

Igi tẹẹée yẹgbó

Òsùmàrè yộrun

A róge-má-séjú ò

İwọ̀n lọràn dùn mọ (Ọbasá 1934: 3).

A tall, slim lady fell upon plates, the plates did not break

(But) she fell upon the mortar, the mortar breaks

A tall, slim lady befits her husband during dancing

A slim tree beautifies the forest

The rainbow beautifies the sky

One who gazes at a beautiful lady intimately

Should be careful not to do that excessively

The excerpt above reveals the Yorùbá view that the appearance of women is always a source of attraction to men. For Ọbasá, natural beauty, body decoration, and proper body care can enhance a woman's beauty and make them attractive. The example below is from the poem titled "Ewà":

Aájò ẹwà ni, aájò ẹwà ni

Elétí n'lutí

Torí aájò ẹwà ni

Olórí n' dirí

Torí aájò ẹwà ni

Tíróò, ọse, kàinrìnkàn, osùn

Gbogbo è, gbògbò è

Torí aájò ẹwà ní

Ewà lowó, owó lẹwà (Obasa, 1934:3).

It is for the care of beauty, it is for the care of beauty

The owner of the ear perforates her ears

All for the care of (her) beauty

The owner of hair plaits her hair

All for the care of (her) beauty

Black lead, soap, sponge, cam wood

Everything, in entirety 
All for the care of (her) beauty

Beauty brings money, beauty is expensive.

From the above excerpt, we can see certain issues that are related to the physical appearance of women and their social interaction with their male counterpart. One, women use various cosmetics for aesthetic purpose. Two, the use of cosmetics in various forms involves women spending money to maintain their beauty. It also shows that Yorùbá women are fashionable. Undoubtedly, Ọbasá's poetry is in line with Yorùbá view that before anyone could be attractive, there is the need for him or her to take proper care of his or her body. It is worthy of note that Obasá appreciates the beauty of women despite gender imbalance in his society.

\section{Women's Character in Obasa's Poetry}

The poet portrays the thoughts and beliefs of Yorùbá on good characters (ìwà omọlúàbí) expected of all human beings. To the Yorùbá people, character is associated with beauty and when one lacks good character, then beauty is nothing. Obasá confirms this in the poem below:

İwà rere lẹsọ́ ènìyàn

İwà, ìà, là n' wá iwà

Bóbinrin dára bi ẹgbárá

Bí kò níwà

Omọlángidi ni

(Ọbasá 1934: 12).

Good character is the beauty of a person

Character is what we desire

No matter how extraordinarily beautiful a lady is

If she lacks good character

She is nothing more than a wooden doll.

From the above, Obasa asserts that good character is vital in human relationship and sustainable development. This is in tandem with Ajibade's (2008) position that, "...good character entices and attracts other people and benefit for vital living, while bad character repels the same...bodily beauty devoid of good character is useless and lifeless since its worth nothing other than a wooden doll" (280). The following excerpt of Ifá poetry also corroborates this Yorùbá view that,

... ló dífá fún Ộrúnmilà 
Baba n'lọ gbé İwà níyàwó

Nígbà tí Ộrúnmilà yóo kộkọ gbéyàwó

İwà ló gbé níyàwó

İwà sí rèé

Sùúrù ló bí i. (Odegbola 2014: 75).

...Divination was performed for Ọrúnmìlà

Ộúnmìlà was getting married to İwà (character)

When Ọrúnmilà wanted to get married

He married İwà (Character)

İwà (Character), the daughter of Patience.

\section{Stereotypical views about Women in Obasa's Poetry}

Many societies in Africa relegate their women to the background and reduce them to mere subordinates. Eventually, some African male writers do injustice to issues that affect female gender because of their patriarchal orientation. According to Eruaga (2018: 212), patriarchy as ideology, privileges a male-centered society and encourages male control. It places authority, control, superiority, and supremacy in the hands of the male, father, brother, and uncle.

Also, Akínyẹmí (1991) states that Ọbasá's view about women reveals that they are talkative, jealous, backbiters, and wayward. But in Akinyemi's view, while there are some women who are bad as pointed out in Ọbasá's poetry, many women are also of good characters. Obasá in his poetry states that,

A kí iyàwó kò jẹ

A fún un lówó

Ó gbówó lọ (Ọbasá 1982: 4).

We greeted the wife but she did not respond

We offered her money

She took it and went away

The impression created in the above poem is that women cherish money more than genuine love. They are thus perceived as tricksters and covetous beings. Furthermore, Obasá in his work presents women as evil. In the poem "Ẹta-Nta-gbá", Ọbasá writes,

Bó o r'Ésù̀ ò yà fún-un

Obinrin Abini b'Èsù

(Ọbasá 1934: 18). 
When you see the devil, move away from him

Women can push one to the devil

Without mincing words, the poet shows that women are personifications of violence. It is clearly noted that this is a misogynous message to disparage the status of women.

Another poem of Obaasa reiterates that women are generally lenient on their children, which may have negative effect on their upbringing. The poem reads thus:

Omọ dá iyá rẹ lójú

Jo mí, jo mí, o kò sàijo mí

Baba ọmọ ní sọ lẹnu

Omọ ẹni ibá jọni

À bá yọ títí

Àwọn obinrin kóbinrin ki i jẹe

Kọ́mọ ó jọ baba rẹ tó bí i (Ọbasá 1934: 19).

It is only the mother who knows the father of her child

Resemble me, resemble me, you must resemble me

The father that insists a child must resemble him must be careful

If one's child resembles one

One will be very happy

Some woman will never allow

The child to resemble his/her biological father

Yusuf (1996) affirms this position as well, that, "As much as mothers can contribute to the development of the society, they can equally destroy the society roles as expected" (75). However, due to the patriarchal stereotype of women, the society shifts all the blames on women on what affect both parents. Another feminine stereotype of women in Ọbasá's work says that,

Ėẹmejì laya olè súnmú sí

Ijọ ọwọ́ ọkọ bá de

Àsèdà ẹran àjẹti

Ojọ́ tộwọ́ bá bọko

Oríàwé di gbii

Nídií òún lọjà ọba

Aya káti ó n' súnmú sí (Ọbasá 1934: 11).

The wife of a thief have running nose twice 
The day her husband succeeds in his business

They will have more than enough to eat

The day her husband is captured

When his head rolls

In Ogun's shrine at the king's market

The above excerpt portrays women as humans who are only out to enjoy. They are not ready to endure the hardships brought about by the setbacks in their husbands' business. The mindset of superiority of men over women is shown in the above excerpt. It is not true that all women abandon their husbands when the family is experiencing difficulties. In the corpus of Ifá, in Ėjìogbè, Ààbò, the wife of Ọrúnmìlà stood by her husband in difficult times,

Òdá owó, awo Kóro

Ààbò, obìnrin rẹ̀...

Bi ọdá owó șe n'da mi.

Bẹé ni Ààbò mi ñ bò mí... (Abimbola 1968: 20).

Òdá owó, the diviner of Kóro

Protection (Ààbò), his wife...

When I was in financial crisis

Protection (Ààbò), my wife stood by me...

Considering the above Ifá corpus, it shows that women can stand as the pillar to rescue their family when there is need for that. Their position in the society is not mainly for cooking and childbearing.

Obasá also portrays women as hypocrites, tale-bearers and backbiters. He writes:

Enu ò mẹ́nu, ètè ò métè

Obinrin kò lè rí kó má wí

Àtàrí obinrin kò gbawo

O délé ó rò fóbinrin

Ó bawo jẹ, ó fáyé lójú (Ọbasá 1934: 21).

They will not keep quiet, they will not keep shut.

Women cannot see without saying it

Women cannot keep secrets

If you reveal secrets to women

They will discuss it in the open, and create problem. 
The above poem shows the patriarchal opinion on women that they cannot keep secrets. In another poem, Ọbasá says:

Panságà abiyakọ bẹere

A ni ogbó mà ń dé

Ó lóun kòi gbó

Obinrin n'hewú

Inú rẹ bàjẹe (Ọbasá 1934: 17).

Adulteress of many mother in-laws

People say, "you are getting older"

She responds, "I am not getting older"

When a woman starts to grow grey hair

She becomes unhappy.

This presentation depicts women as being promiscuous. Although both genders are supposed to bear the blame men are left out because of gender bias and patriarchal hoax that exists in the society.

\section{Conclusion}

This essay has discussed the depiction of women in Obasáa's poetry, a topic that has not been given adequate attention by earlier scholars. The study reveals that the representation of women in the poetry of Obasa did not go beyond the stereotypical and derogatory portrayal of women among the Yoruba. Our position is that Obasá should have devoted a number of his poems to men's attributes as well. That would ensure gender balance. Finally, authors of literary works should pay more attention to the positive roles of women in the society without prejudice or bias.

\section{References}

Abímbọ́lá, W. (1968). İjìnlẹ Ohun Ẹnu Ifá Apá Kiíní. Glasgow. Collins, Sons and Co. Ltd.

Abímbọ́lá, W. (1976). Ifá: An Exposition of Ifá Literary Corpus. İbàdàn: Oxford University Press.

Acholonu, C.O. (1995). Motherism, the Afro Centric Alternative to Feminism. Oweri: Afa Publications.

Adébọ̀wálé, O. (1999) "İfojú Tíónì İṣègbèfábo wo Ipò Obìnrin nínú Ėtò İgbeyàwó: Àyẹ̀wò İtàn Àròsọ Yorùbá”. Yorubá: A Journal of Yorùbá Studies Association of Nigeria vol. 1, No. 1, o.i. 9-18. 
Adéjùmọ̀, A. (1999). "İfojú Tíọini İșègbèfábo wo eré-Onítàn Yorùbá tí Obìnrin kọ”. Yorubá: A Journal of Yorùbá Studies Association of Nigeria vol. 1, No. 1, o.i.19-27.

Adéjùmọ̀, G.A. (2017). “Ipò wo Lobìnrin Wà nínú İtàn Àròsọ Fágúnwà?” in Adélékè A. and Adésộkàn, A. (ed.) Celebrating D.O. Fágúnwà. Aspect of African and World Literary History. İbàdàn: Bookcraft Publication. Pp. 176-191.

Ajíbádé, G.O. (2008). "Representation of Gender Discourse in the Poetry of Akinwumi Isola" Akinyemi Akintunde. and Toyin Falola (Eds.) Emerging perspectives on Akinwumi Isola Trenton, New Jersey: Africa World Press, Pages 273-288.

Ajíbádé, G.O. (2019). Yorùbá Folklore: People’s Pulse and Imaginations. An Inaugural Lecture Delivered at Odùduwà Hall, Obáfẹ́mi Awólọ́wọ̀ University, Ilé-Ifẹ̀, Nigeria. On Tuesday $28^{\text {th }}$ May, 2019.

Akinyemi, A. (1987). "Déńrelé Adéètìmíkàn Ọbasa (1927-1945) - Akéwì Aláròjinlệ”. M.A. Dissertation, Ọbáfẹ́mi Awólọ́wọ̣ University, Ilé-Ifẹ̀.

Aransi, A. (2017). İsẹtộfábo nínú Àșàyàn Ewì Òn kộwé-Bìnrin Yorùbá. İbàdàn: University Press Plc.

Bọ́lárìnwá, A. (2019). “Women in Adéb|áyọ̀ Fálétís Poetry" in Yorùbá Studies Review 3(2): 135-137.

Chukwung H. (1990/91). "Viewpoint: Feminism is not a Question of Superiority", in Ofirima African Literature and the Era of Gorbarchism, (3): 57-58.

Eruaga, A.O. (2018). "Patriarchy and Illusion of Women Empowerment in Ahmed Yerim'as Jakadiya" in Osisanwo A., Adebiie-Adelabu K., and Mosobalaje, A. (ed.) Literary and Linguistic Perspectives on Orality, Literarcy and Gender Studies: A Celebration of Oluwatoyin Jẹgeẹdẹ @ 60. İbàdàn: Kraft Book Limited. Pp. 212.-215.

Grimke, S.M. (1970). Letters on the Equality of Sexes and the Condition of Women, Boston: Source Book Press.

Ilésanmí, T.M. (2013). Obinrin: A Critical Assessment of Yorùbá Women. İleșà: Multi-Media Press.

Kọláwọlé, M.E.M. (1997). Womanism and African Consciousness. Trenton New Jersey: Africa World Press.

Nnodim, R. (2006). “Audiences in Yorùbá Novel, Print and Media Poetry" Research in African Literatures 37(3): 154-75.

Ọbasá, D.A. (1927). İwé Kejì ti Àwọn Akéwì. İlàrẹe Press, İbàdàn.

Ọbasá, D.A. (1927). İwé Kẹta ti Àwọn Akéwì. İlàrẹe Press, İbàdàn.

Ọbasá, D.A. (1927). İwé Kiíní ti Àwọn Akéwì. Ìlàrẹe Press, İbàdàn, Àtúntẹ O.U.P. İbàdàn (1982)

Odegbola, I.O. Iwe Mimo Ifa: Esin Akoka Olodumare. Ibadan: Odegbola Traditional Global Services. 
Ògúnsínà, B. (1997). "Gender Ideology: Portrayal of Women in Yorùbá İjálá”. Inquiry in African Languages and Literature pp 78-91.

Ọlálẹeyẹ, S. K. (2015). “The Disposition of Odù Ẽgúntánsệ” in Ifá Corpus to Homosexuality" A Journal of Yorùbá Studies Association of Nigeria. 8(1): 56-59.

Òpádọtún, T. (1981). Ewì Àsikò. Ibàdàn: Oníbọn-Oje Publishers.

Ọpẹ́fèyítìmí, A. (2009). "Semiotic and Stylistic Analysis of Yorùbá women Food Hawking Chants" in Ọpẹ́fèyítìmí, A. (ed). Women in Yorùbá Culture (A Dozen of Academic Articles). İbàdàn: Penthouse Publications.

Ọpéfèyítìmí, A. (2009). "Womb to Tomb: Yorùbá Women Power Over Life and Death" in Women in Yorùbá Culture (A Dozen of academic Articles). İbàdàn: Penthouse Publications Nigeria.

Sheba, J.O. (996). "İfojú-Ėrò İṣègbèfábo Șàtúpalẹ ișẹ́ Àwọn Àsàyàn Òn kọ̀wékùnrin Yorùbá”. Ph.D. Thesis, Department of African Languages and Literature, Faculty of Arts, Obáfẹ́mi Awólộwọ̀ University, Ilé-Ifẹ̀.

Sheu, F.S. (2001). "Female in Female: A Critical Examination of Four Yorùbá Female Writers". M.A. Thesis, University of İbàdàn.

Yerima, A. and Aliyu, (2012). Gender Politics: Women's Writings and Film in Northern Nigeria. İbàdàn: Kraft books Limited.

Yusuf, Y.K. (1996). "Roles of Nigerian Mothers in the Moral Development of the Child." Journal of Women in Colleges of Education. 1.1: 72-76. 